\title{
Healing Processes in Cancellous Bone
}

\author{
Magnus Bernhardsson
}

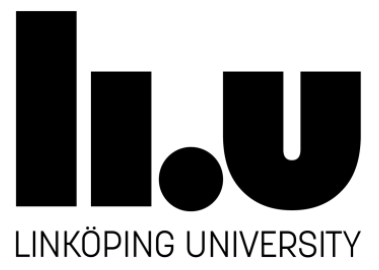

Division of Clinical Sciences

Department of Clinical and Experimental Medicine

Faculty of Medicine and Health Sciences

Linköping University

Linköping, Sweden 2018 


\section{Supervisor Anna Fahlgren}

Associate Professor

Department of Clinical and Experimental Medicine

Linköping University

\section{Co-supervisor Jörg Schilcher}

Associate Professor

Department of Orthopedics and Department of Clinical and Experimental Medicine Linköping University

\section{Faculty Opponent Georg Duda}

Professor

Julius Wolff Institute, Charité

University Medicine Berlin

(C) Magnus Bernhardsson 2018

Published articles have been reprinted with permission of the respective copyright owners.

Printed by LiU-Tryck, Linköping, Sweden, 2018

ISBN: 978-91-7685-177-7

ISSN: 0345-0082 
Till minne av Per Aspenberg 


\section{ABSTRACT}

Most of what is known about the biological response during fracture healing comes from numerous animal studies with shaft fractures in the long bone. However, most patients suffer from fractures closer to the ends of the long bones, in the hip, or in the vertebrae. These types of fractures mainly involve cancellous bone, while shaft fractures concern cortical bone. Compared to cortical bone whose structure is dense and compact, cancellous bone is of spongy and porous structure. A growing number of studies point towards that cortical and cancellous bone heal differently. To even this imbalance in knowledge between these two types of bone tissue, further studies in cancellous bone are justified.

In this thesis we delved into the quiet unknown processes behind cancellous bone healing.

In the first study we characterized and compared two models for cancellous bone healing in mice and rats: the first model can be used to analyze the morphology and morphometry of the regenerating bone; the second model can measure the mechanical properties of cancellous bone. The two models correspond in their developing patterns during the first week before they diverge. This suggests that these models can be utilized together to evaluate the initial healing in cancellous bone. Furthermore, we saw in the drill hole model that the bone formation is strictly restricted to the traumatized region, with a distinct interface to the adjacent uninjured tissue.

The second study characterized the cellular response during the initial healing phase in cancellous bone. The focus was to follow the spatial location of inflammatory and osteogenic cells over time in a cancellous bone injury. In contrast to shaft fractures (cortical bone), where healing is described as sequential events where inflammatory cells are the first to arrive to the trauma before osteogenic cells are recruited and initiate healing, we could see how inflammatory and osteogenic cells appeared early, simultaneously after a cancellous bone injury. This study showed that cancellous bone differs from how fracture healing is normally described.

In the third study we explored the role of a subpopulation of lymphocytes (CD8 positive cells), earlier studied in shaft fractures. We wanted to see how their absence would affect the healing in a cancellous bone injury. Without $\mathrm{CD}^{+}$cells, cancellous bone healing was impaired as expressed via poorer mechanical properties of the regenerated bone tissue.

The fourth and last study issued the influence of uninjured bone marrow on cortical bone healing. We developed a cortical defect model which blocked uninjured marrow from reaching the defect. Without the presence of marrow, the cortical defects ability to regenerate was significantly impaired. This implies that the marrow is important for cortical bone healing.

In conclusion, cancellous bone healing is different from its cortical counterpart and the general perception of fracture healing. We have briefly discerned healing mechanisms in cancellous bone that might be of clinical importance: the restricted cancellous bone formation is something to take into consideration when performing arthrodeses; and importance of marrow in skeletal defects (e.g. pseudarthroses). With this thesis, we hope to promote that further investigating on cancellous bone healing is necessary. 


\section{POPULÄRVETENSKAPLIG SAMMANFATTNING}

Skelettet är ett ytterst dynamiskt organ som är under ständig ombyggnad och är involverat $\mathrm{i}$ flera fysiologiska processer i våra kroppar. Den mineraliserade benvävnaden kan delas upp i två kategorier: kortikalt och spongiöst ben. Kortikalt ben är det hårda och kompakta höljet som innesluter benens innanmäte. Spongiöst ben är mer porös i sin uppbyggnad och finns i riklig mängd i ändarna på rörben, i höftben och i ryggkotor.

När ett ben utsätts för ett trauma, till exempel vid ett fall, som är kraftigare än vad benet tål så går det sönder och det bildas en fraktur. Vi har idag mycket kunskap om vad som sker efter frakturer i mitten på rörben, så kallade skaftfrakturer. Detta är frakturer som främst berör kortikal benvävnad. Varför vi vet mer om dessa frakturer är på grund av enkelheten att studera detta i djurförsök. Patienter råkar dock ofta ut för handleds- och höftfrakturer - frakturer som involverar spongiöst ben i högre grad. Mycket tyder på att kortikalt och spongiöst ben läker olika på grund av skillnader i deras biologiska sammansättning. Obalansen i kunskapsnivå kontra frakturfrekvens mellan dessa två benvävnader talar för att fler studier om spongiös benläkning bör utföras. Detta motiverade oss att undersöka läkningsprocesser i spongiöst ben.

Först la vi märke till att läkning i spongiöst ben är ytterst begränsad till det skadade området. Det var en skarp avgränsning mellan den angränsande oskadda vävnaden och det nybildade benet i skadan som endast bredde ut sig ett par millimeter. Detta skiljer sig från hur kortikalt ben vanligtvis läker där man ofta ser en expanderande nybildad vävnad, även kallad för kallus. Den begränsade benbildningen i spongiöst ben kan förklara varför steloperationer har svårigheter att läka. Steloperationer går ut på att foga ihop separata ben för att lindra smärta $\mathrm{i}$ en led och genomförs genom att två ytor av spongiöst ben förs samman för att läka ihop. Överskrider mellanrummet mellan ytorna endast ett par millimeter riskerar ytorna att inte läka ihop.

Vi kunde också se hur celler från immunförsvaret tidigt dök upp i den spongiösa skadan, samtidigt som benbildande celler. Frakturläkning brukar annars beskrivas som ett sekventiellt förlopp där immunceller anländer först för att sedan locka dit benceller. Utifrån våra fynd drar vi slutsatsen att benbildande celler i spongiös benvävnad kan reagera på trauman självständigt och snabbt påbörja läkning på egen hand.

I en annan studie undersökte vi hur viktig benmärgen är vid läkning av en kortikal benskada. Vi blockerade benmärgens åtkomst till en nybildad skada i det kortikala benet. I de skador där benmärgen inte var blockerad kunde vi se hur skadan läkte ihop med nytt ben. Däremot i de skador där benmärgen var blockerad kunde vi inte se någon läkning eller nybildat ben. Detta tyder på att närvaron av benmärg vid kortikala benskador är av betydelse och nödvändig.

Sammanfattningsvis har vi påvisat att spongiös benläkning skiljer sig från den konventionella beskrivningen av frakturläkning. Frakturläkning är en mångfacetterad process som inte kan summeras i ett och samma förlopp. Framtida forskning inom området bör uppmärksamma vilken/vilka benvävnader det är man faktiskt studerar. 


\section{LIST OF PAPERS}

I. Bernhardsson M, Sandberg O, Aspenberg P.

Experimental models for cancellous bone healing in the rat.

Acta Orthopaedica 2015; 86(6): 745-50.

II. Bernhardsson M, Aspenberg P.

Osteoblast precursors and inflammatory cells arrive simultaneously to sites of a trabecular-bone injury.

Acta Orthopaedica 2018; 89(4): 457-461.

III. Bernhardsson M, Dietrich-Zagonel F, Tätting L, Eliasson P, Aspenberg P.

Depletion of cytotoxic $\left(\mathrm{CD}^{+}\right) \mathrm{T}$ cells impairs implant fixation in rat cancellous bone.

Manuscript.

IV. Bernhardsson M, Tätting L, Sandberg O, Schilcher J, Aspenberg P.

Marrow compartment contribution to cortical defect healing.

Acta Orthopaedica 2018; 89(1): 119-123. 


\section{Additional papers not included in this thesis}

Bernhardsson M, Aspenberg P.

Abaloparatide versus teriparatide: a head to head comparison of effects on fracture healing in mouse models.

Acta Orthop. 2018: 1-6.

Bernhardsson M, Sandberg O, Ressner M, Koziorowski J, Malmquist J, Aspenberg P. Shining dead bone-cause for cautious interpretation of $\left[{ }^{18} \mathrm{~F}\right] \mathrm{NaF}$ PET scans.

Acta Orthop. 2018; 89(1): 124-127.

Sandberg OH, Tätting L, Bernhardsson ME, Aspenberg P.

Temporal role of macrophages in cancellous bone healing.

Bone. 2017; 101: 129-133.

Tätting L, Sandberg O, Bernhardsson M, Ernerudh J, Aspenberg P.

Isolated metaphyseal injury influences unrelated bones.

Acta Orthop. 2017; 88(2): 223-230.

Sandberg O, Bernhardsson M, Aspenberg P.

Earlier effect of alendronate in mouse metaphyseal versus diaphyseal bone healing.

J Orthop Res. 2017; 35(4): 793-799.

Bernhardsson M, Sandberg O, Aspenberg P.

Anti-RANKL treatment improves screw fixation in cancellous bone in rats.

Injury. 2015; 46(6): 990-5. 


\section{TACK}

Många har varit inblandade och bidragit till att denna avhandling blev till och jag är oerhört tacksam inför alla som jag har fått träffa under färden! Det finns dock de som jag vill uttrycka några ytterligare ord om vördnad till:

Per Aspenberg, utan dig hade jag inte varit där jag är idag, tack för att du trodde på mig. Din glöd må ha slocknat, men den lever vidare i oss alla som har berörts av dig.

Anna Fahlgren, Jörg Schilcher och Pernilla Eliasson, för att ni hjälpte mig att ro denna avhandling i hamn. Ert enorma stöd och rådgivning har varit ovärderlig.

Olof Sandberg, för att du visade vägen och hade tålamod med mig och alla mina frågor i början.

Malin Hammerman, Parmis Blomgran, Love Tätting, Franciele Dietrich-Zagonel, Cornelia Bratengeier och Mehdi Amirhosseini, för all er hjälp, samarbete och sällskap på labbet samt kontoret.

Alla som jobbat/jobbar på djuravdelningen, tack för ert alltid positiva bemötande och villighet att ställa upp när man frågar om hjälp.

Alla på tidigare KEF och på Cellbiologen plan 10, tack för trevligt sällskap i fikarummet.

Mina föräldrar och syskon med familjer, för den trygghet och uppmuntran ni ger mig som får mig att våga ta det extra steget.

Min älskade fru Varre, hade jag inte haft dig vid min sida hade denna resa varit betydligt tuffare. Du håller mig uppe vid motgång och får mig att blicka framåt istället; med samma engagemang delar du också min glädje vid framgång. ขอบคุณมากๆที่รักครับ รักตลอดไปครับ 


\section{TABLE OF CONTENTS}

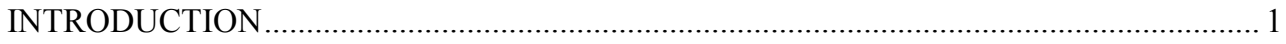

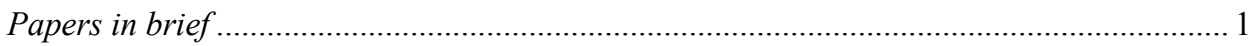

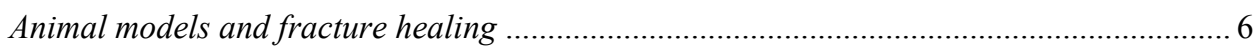

Drill holes and screws for studying bone healing? ............................................................ 6

HEALING PROCESSES IN CANCELLOUS BONE....................................................... 9

Bone marrow cells respond - independently - to trauma .................................................. 11

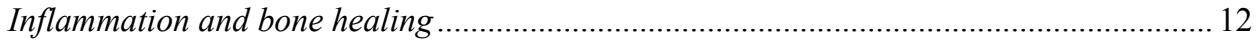

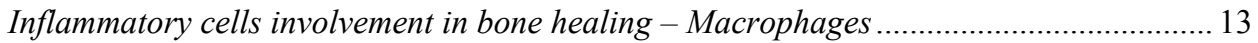

Inflammatory cells involvement in bone healing - Cytotoxic T cells .................................. 14

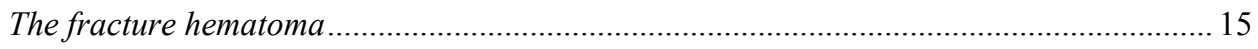

Cortical bone cannot heal without the influence from bone marrow ................................... 15

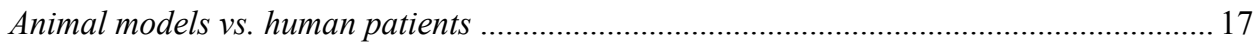

SUMMARY AND REMARKS FOR FUTURE RESEARCH .............................................. 19

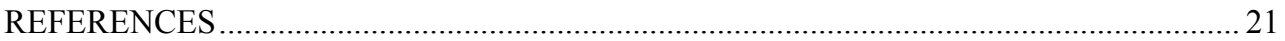





\section{INTRODUCTION}

Bone is a dynamic tissue which constantly remodels itself, and with the unique ability to heal without any scar formation. ${ }^{1-6}$ Bone tissue can be distinguished into two types: cortical bone dense and compact in structure, forming an outer hard shell around bones; and cancellous bone - spongy and porous in structure, located in the ends of long bones, the hip, and the vertebrae.

When a bone is exposed to a force higher than it can support it will break, creating a fracture. Fracture healing is described in the literature as a sequential process with overlapping phases: inflammation - accumulation of inflammatory cells; soft callus formation - cartilage formation; hard callus formation - the cartilage is mineralized and becomes new woven bone; and bone remodeling - the woven bone is replaced by lamellar bone which is more organized and stronger. ${ }^{2,4,13,5-12}$ This process mainly concerns cortical bone healing in so called shaft fractures. Much is known about these types of fractures because they are relatively easy to study in animal models. However, the most common fractures in patients occur in cancellous bone - wrist fractures and vertebral compression fractures. ${ }^{14,15}$ Cancellous bone healing is more or less devoid of soft callus formation, able to form new bone directly and more rapidly within the confinement of the injured site compared to shaft fractures. ${ }^{16-19}$ More and more studies point towards a difference between cortical and cancellous bone in their healing and response to treatments; ${ }^{19-22}$ this implies the need for more studies in cancellous bone.

In this thesis, we explored mechanisms behind the rather unfamiliar healing processes in cancellous bone.

\section{Papers in brief}

Initially, our ideas for this thesis came from a clinical study on patients with distal radial fractures, where biopsies from the healing region were studied under the microscope. ${ }^{23}$ Bone formation is thought to start from already existing bone surfaces, such as damaged trabeculae, which will expand and fill out defects. ${ }^{24}$ Whereas in the distal radial biopsies, new bone formation could be seen located freely in the bone marrow with minor signs of contact with adjacent old trabeculae, and cartilage formation. It seemed that the bone marrow cells were able to respond independently to the trauma and form bone directly in the marrow space without contribution from old bone surfaces.

This observation gave inspiration to explore the role of the marrow in cancellous bone, and its seeming ability to form new bone directly. Four studies were conducted and included into this thesis: the first describes two models for cancellous bone healing; the second focus on the initial healing phase and different cell types involved in cancellous bone healing, including a minor cell depletion study; the third is a cell depletion study, which monitor the involvement of a certain lymphocyte subpopulation in cancellous bone healing; the forth describe the role of the marrow in cortical bone healing. 


\section{Paper I - Experimental models for cancellous bone healing in the rat.}

Aim: Compare and evaluate implanted screws and drill holes in cancellous bone as models for bone healing.

Method: Bilateral drill holes were made in proximal tibiae in rats. In one drill hole a steel or a radiolucent PMMA screw was inserted (Figure 1). Pull-out force of the implanted steel screws was mechanically tested, and bone formation in the drill holes and around the PMMA screws were measured using microCT after 1, 7, 14 and 28 days.

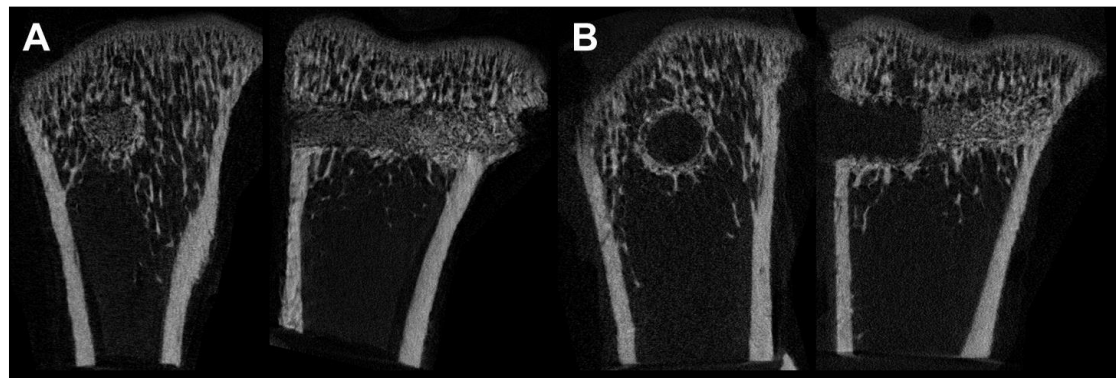

Figure 1. Radiographic images of $(A)$ a drill hole, and (B) a PMMA screw in proximal tibia, one week after surgery.

Results: The pull-out force of the screws increased during the first week (Figure 2A) as well as the bone formation in the drill holes and around the PMMA screws (Figure 2B-C). Although the bone formation declined thereafter.
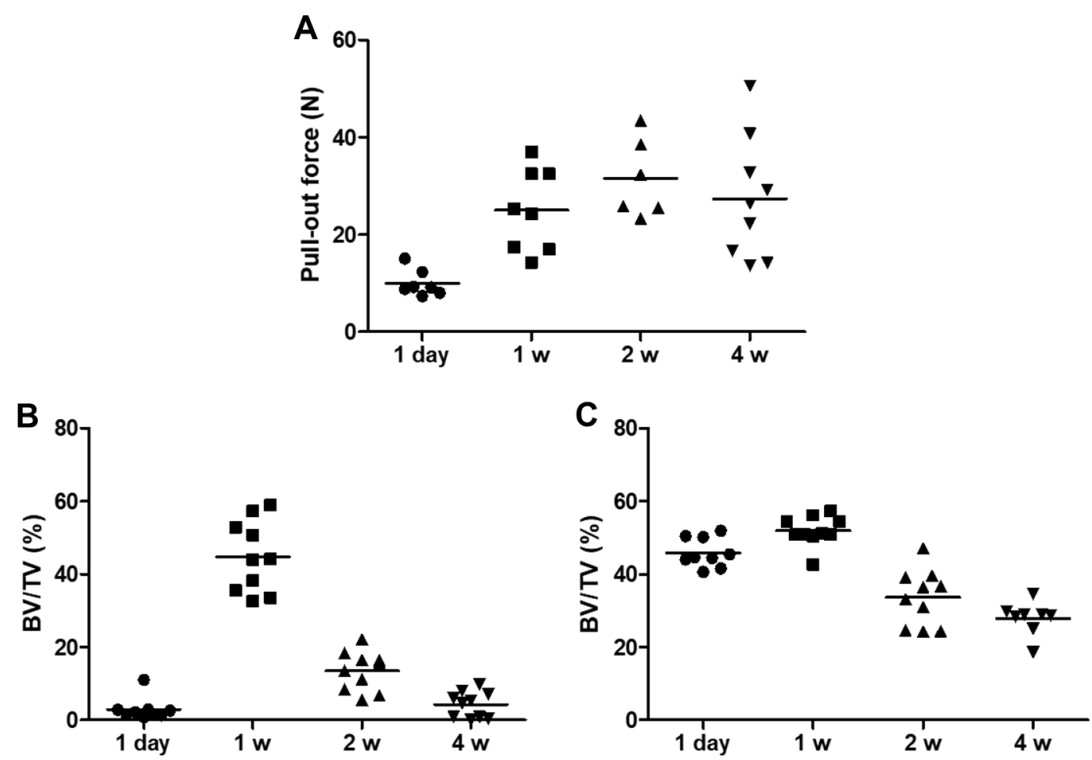

Figure 2. (A) The pull-out force of steel screws gradually increased up to two weeks but would not change after that. (B) The bone volume (BV/TV) inside the drill holes and (C) around PMMA screws peaked after one week before it declined. 
Conclusion: Pull-out force and bone formation corresponded during the first week, and appear to reflect a bone-healing response, before they deviate in different directions.

\section{Paper II - Osteoblast precursors and inflammatory cells arrive simultaneously to sites of a trabecular-bone injury.}

Aim: Monitor the initial healing response and the importance of timing and arrival of inflammatory, and osteogenic cells in a cancellous bone injury.

Method: A drill hole was made in the proximal tibia in rats. From day one to five the tibiae were stained for inflammatory (granulocytes and macrophages), and osteogenic cells (mesenchymal cells and preosteoblasts) using immunohistochemistry. The number of stained cells were later quantified in the healing bone tissue.

A subgroup of animals received a single injection of clodronate liposomes, to deplete macrophages, either 24 hours before or after a drill hole was made in their proximal tibia. After a week, the bone formation in the drill holes was quantified by microCT.

Results: Granulocytes could be seen in moderate numbers by the first day within the hole, before they gradually disappeared (Figure 3A). A modest number of macrophages were seen the first two days before they increased by day three, and then decreased (Figure 3B). Mesenchymal cells accumulated in the periphery of the hole already at day one, and by day three they dominated the entire region of the lesion (Figure 3C). A few preosteoblasts were seen at day one and peaked by day four (Figure 3D).

A

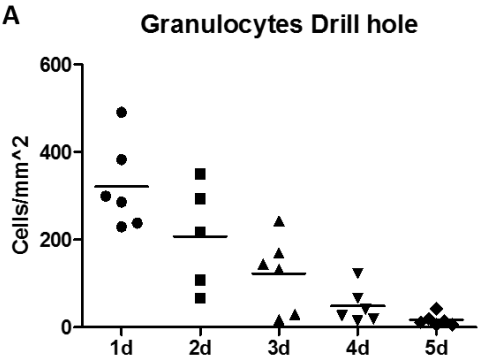

C Mesenchymal cells Drill hole

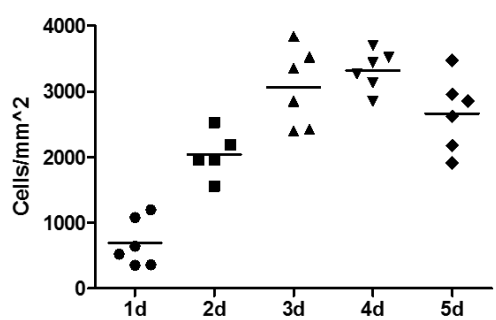

B

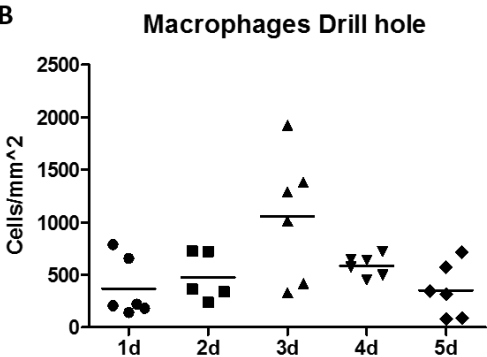

D

Preosteoblasts Drill hole

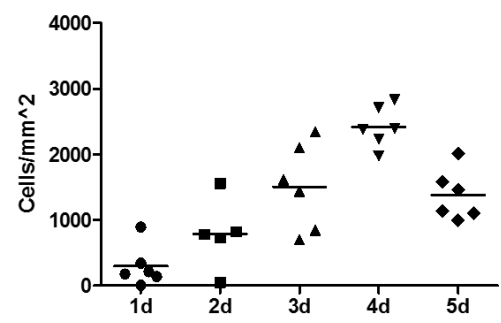

Figure 3. Quantification of cell populations in drill holes in proximal tibia. (A) Granulocytes decreased in numbers over time. (B) Macrophages increased in numbers and peaked by day three before they decreased. (C) Mesenchymal cells numbers raised rapidly up to day three and peaked by day four. (D) Preosteoblasts increased gradually and peaked by day four before their numbers declined. 
Clodronate liposomes given 24 hours before injury reduced bone volume (BV/TV) by 33\% compared to controls, while administration 24 hours after injury had no such effect (Figure 4).

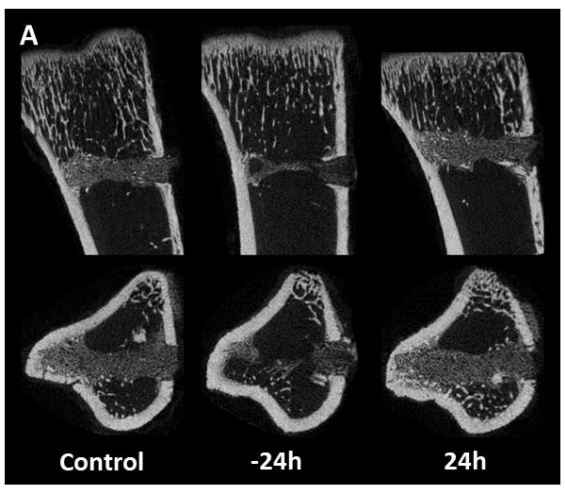

B

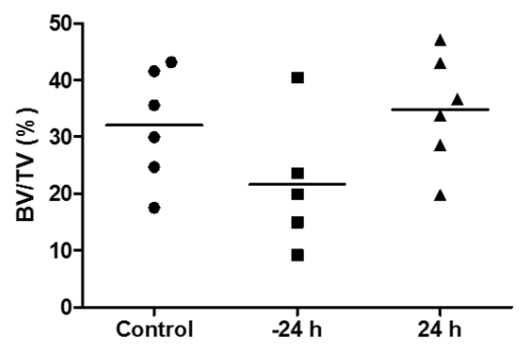

Figure 4. MicroCT analysis of drill holes in proximal tibia, one week after trauma. (A) Radiographic images showing drill holes. (B) Measurement data of bone formation (BV/TV) in drill holes; clodronate reduced bone formation by $33 \%$ when given 24 hours prior to trauma $(-24 \mathrm{~h})$ compared to controls. When given 24 hours after trauma $(24 \mathrm{~h})$ no effect on bone formation could be seen.

Conclusion: Mesenchymal and inflammatory cells appear to be activated simultaneously upon trauma in cancellous bone. This is different from the sequential events in shaft fracture healing, were inflammatory cells are the first to arrive to the injured site before mesenchymal cells are recruited and initiate healing.

Clodronate liposomes impairs bone formation, suggesting that the presence of macrophages in the injury during the first day is crucial. However, there is a possibility that the reduced bone formation is due to a direct inhibitory effect of clodronate itself which cannot be ruled out.

\section{Paper III - Depletion of cytotoxic $\left(\mathrm{CD8}^{+}\right) \mathrm{T}$ cells impairs implant fixation in rat cancellous bone.}

Aim: Deplete cytotoxic $\left(\mathrm{CD}^{+}\right) \mathrm{T}$ cells and study the effects in a cancellous bone injury.

Method: Bilateral drill holes were made in the proximal tibiae in rats, where one hole received a steel screw. Anti-CD8 antibodies were injected 24 hours prior to the trauma to deplete CD $8^{+}$ cells. After a week, the pull-out force of the screws was mechanically tested and bone formation in the drill holes was measured with microCT.

Results: Anti-CD8 antibodies showed no effect on bone formation in the drill holes. However, the pull-out force and stiffness were reduced by $19 \%(\mathrm{p}<0.05)$ and $34 \%(\mathrm{p}<0.01)$ respectively compared to the controls (Figure 5). 

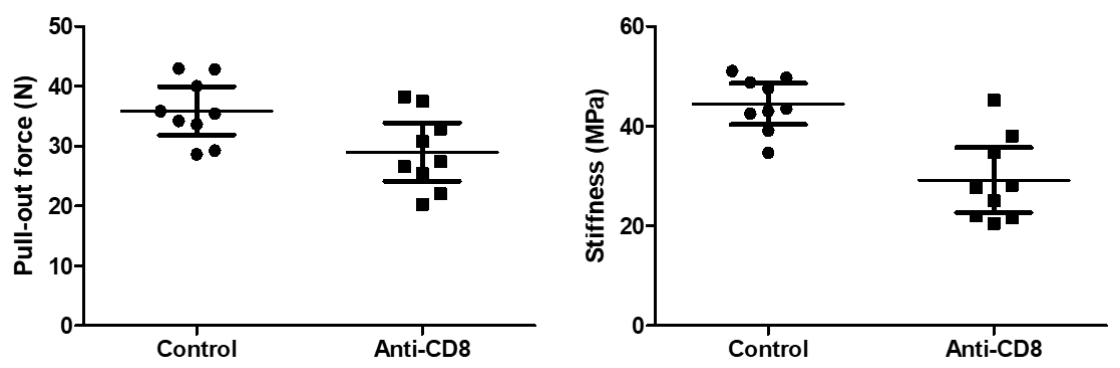

Figure 5. Results from mechanical evaluation of implanted screws, one week after insertion (lines representing the mean and bars $95 \%$ confidence intervals). Anti-CD8 antibodies reduced the pull-out force by $19 \%(p<0.05,95 \% \mathrm{Cl}: 3$ to 35$)$ and stiffness by $34 \%(p<0.01,95 \% \mathrm{Cl}$ : 18 to 50$)$ compared to controls.

Conclusion: Depletion of $\mathrm{CD}^{+}$cells prior to implant insertion impairs fixation, suggesting that $\mathrm{CD}^{+}$cells are important during the first day for a proper healing response.

\section{Paper IV - Marrow compartment contribution to cortical defect healing.}

Aim: Explore the influence of the neighboring, uninjured marrow on cortical bone healing in mice.

Method: In mice, a groove was milled along the femoral shaft, followed by removal of the bone marrow in the area of the cortical defect. Next, two silicone plugs were inserted into the marrow compartment, distal and proximal to the defect, thus preventing the remaining marrow to enter the injury. The mice were killed five or ten days after injury, their femurs harvested and prepared for histology with H\&E staining.

Results: After five days, the defects without plugs showed regeneration of bone marrow-like tissue in the defect (Figure 6A). In contrast, no regeneration could be seen in those with silicone plugs (Figure 6B).
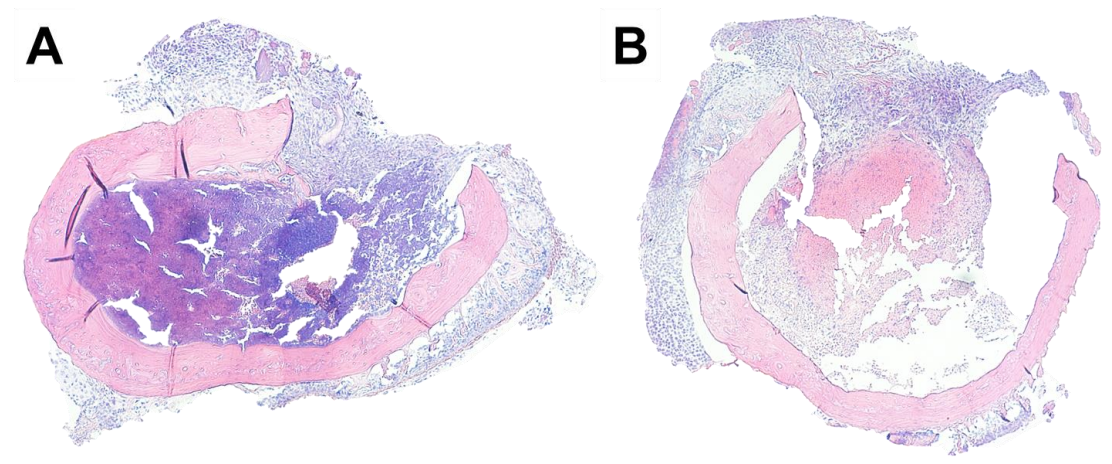

Figure 6. H\&E staining of five-days-old cortical defects. (A) New bone marrow-like tissue (purple) could be seen in the controls and inflammatory cells filling the cortical gap. (B) In the silicone-plug group, no regenerated tissue in the marrow compartment could be seen. 
After ten days, the cortical gap was lined with new bone in the femurs without plugs (Figure 7A). No regeneration or bone formation could be seen when silicone plugs were used (Figure 7B).
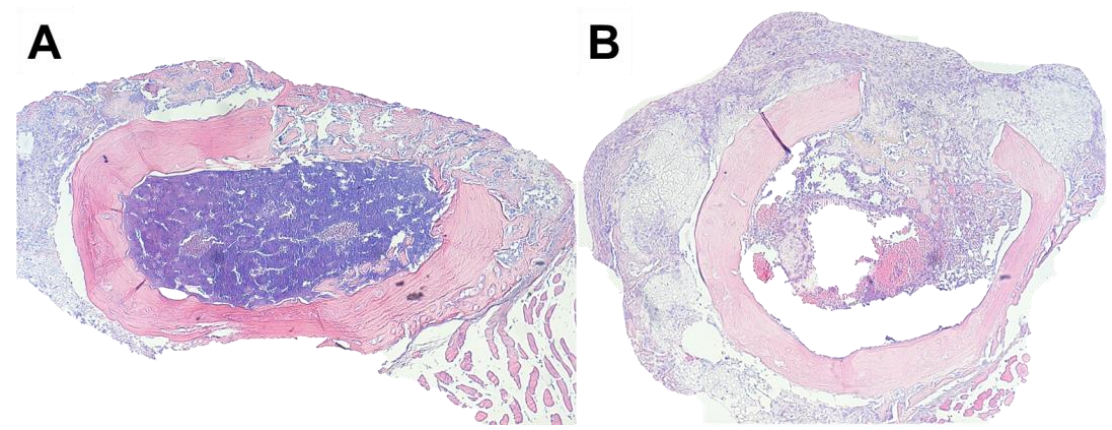

Figure 7. Ten-days-old cortical defects. (A) Complete cortical bridging, with a distinct interface between the regenerated marrow-like tissue (purple) and newly formed bone could be seen in the controls. (B) No tendencies to cortical bridging could be seen in the silicone group, however, some animals showed newly formed bone in the marrow compartment.

Conclusion: The absence of bone marrow impairs the healing of cortical defects in mice; the presence of bone marrow seems to have an important part in the healing process of cortical bone.

\section{Animal models and fracture healing}

Usually when studying fracture healing in animal models, you break a long bone in half, leave it to heal, and then measure the force required to break it again - to get a measure on how well it has healed. The force is measured by a so called three-point-bending test where the bone is placed on two supporting points before a force is applied in the middle of the bone, pushing it downwards until it breaks. ${ }^{25,26}$

This method however, primarily measures the strength of the bone cortex (cortical bone) and bending resistance. Cancellous bone is not constructed to resist bending forces but rather compressive ones; this makes it difficult to evaluate cancellous bone mechanically.

\section{Drill holes and screws for studying bone healing?}

To study healing in cancellous bone, our group has developed a model where a syringe needle is used to drill a hole in the proximal metaphysis in the tibia in rats or mice. The drilling of the hole will trigger a healing response which will fill the drill hole with new - rather dense - bone in less than a week, with the shape of a cylinder and a distinct border between the new bone and uninjured tissue.

If you insert a screw into the hole after it is made, the healing response will form new bone around the screw threads instead - holding the screw. When the screw is pulled, the bone around the screw is exposed to compressive forces, and more bone - or bone of better quality - means a higher compression resistance. That is, a higher/better bone formation means a greater force is required to pull the screw out. This way we can measure the pull-out force of the screw to estimate cancellous bone healing mechanically as well. 
We have used these two models (drill hole and screw) in several pharmacological experiments and seen that bone anabolic or anti-catabolic drugs increase both bone formation in the drill holes and pull-out force of the screws compared to non-treated controls. ${ }^{22,27,28}$

Over the years, the screw model has been criticized, not seen fit as a model for studying fracture healing in cancellous bone. We agree, it is not a fracture-healing model, it is a bone-healing model; we see the drill-hole model more as a bone-healing model as well, rather than a fracturehealing model.

Our aim with these models is not to study fractures in order to come up with new treatments that can be used in the clinic; our aim is to study healing processes to get a better understanding of the mechanisms involved. An understanding which in the future may help others to develop treatments that can be applied in a clinical setting. That is what we use our models for - to study healing processes in a controlled setting that is standardized and to be able to generate reproducible data. 


\section{HEALING PROCESSES IN CANCELLOUS BONE}

The idea for this thesis came from an observation in biopsies from patients with distal radial fractures. ${ }^{23}$ In contrast to the belief that bone healing originates from old bone tissue ${ }^{24}$ the biopsies showed new bone formation in the marrow - distant from other bone surfaces. This finding suggest that marrow cells can respond to trauma independently. To investigate this phenomenon further, we began with a pilot experiment.

The focus of the pilot experiment was to see how small of an injury we could make to induce bone formation in the marrow, with as little involvement from cortical bone as possible. We did this by milling away the cortical bone before piercing the marrow, in the distal metaphysis, with a thin razor blade. In a few of these specimens we could see a delicate formation of bone, with the shape of a thin sheet, where the razor blade just had pierced the marrow (Figure 8). However, we discarded this model since we were unable produce these thin bone sheets with a sufficient reproducibility. Instead we decided to use our simpler drill-hole model.

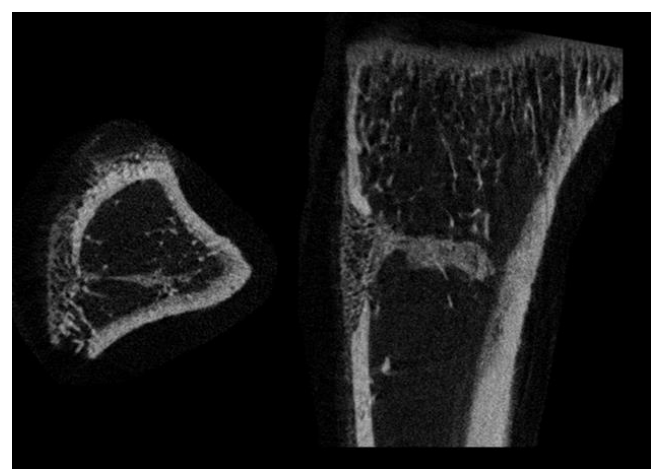

Figure 8. Radiographic image of rat tibia showing restricted bone formation in the marrow compartment, one week after being pierced with a razor blade (left image: transverse plane; right image: sagittal plane).

Even though our group has been using this model for years, it was not until this time that we started to pay attention and question something that we had taken for granted. A week after the drill holes are made, you can see this strictly localized bone formation: spreading less than a millimeter from the traumatized region, which we had not thought about earlier.

After searching the literature to see if anyone else had observed this phenomenon, we found a publication from the 1950s by the British orthopedic surgeon John Charnley. ${ }^{29}$ While working with knee arthrodeses, Charnley saw the same thing as us, but in human biopsies from the intersection surfaces of the bones. The bone formation in the cancellous tissue would not reach further than a couple millimeters from the traumatized regions (Figure 9). This observation has been largely neglected since then, but nonetheless it is an important one; arthrodeses are well known for their healing problems, and this restricted bone formation in cancellous bone might explain why. Because, if the gap between the intersection surfaces is greater than just a couple 
of millimeters, the surfaces will not fuse together - jeopardizing the healing and increase the risk for revision surgery.

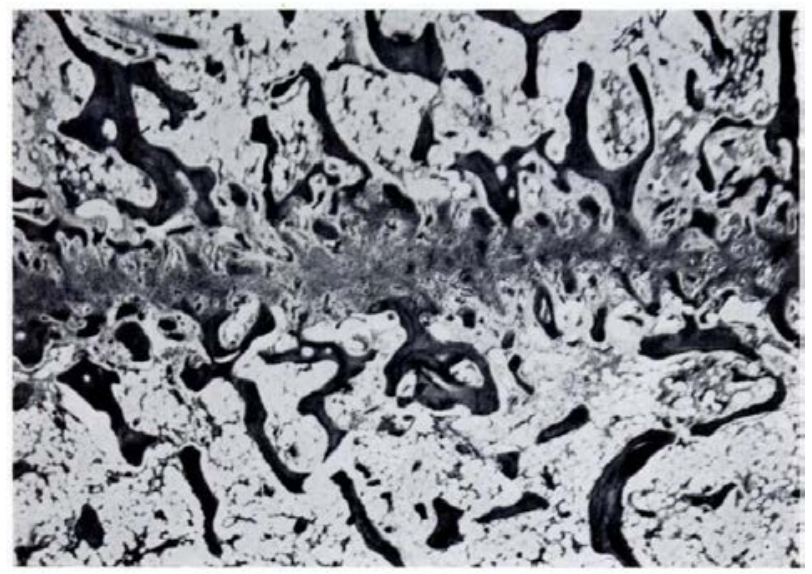

Figure 9. Human biopsy from a four-weeks-old knee arthrodesis showing bony union between the tibia and femur (black color represents bone tissue). ${ }^{29}$ Note the strictly localized bone formation between the intersection surfaces (grey area in the middle). Image included with permission.

Marveled by this - not earlier questioned - observation and asking ourselves why cancellous bone formation is so strictly confined to the traumatized region, we believed that there must be a biological difference between the injured and the uninjured tissue (Figure 10).

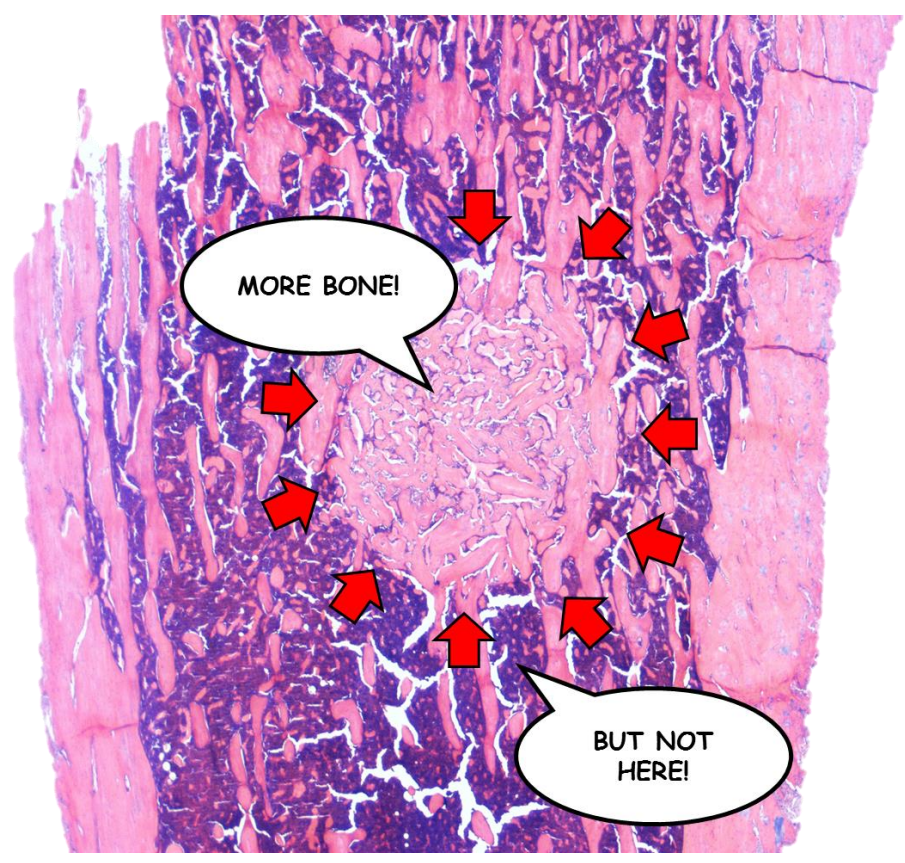

Figure 10. Rat tibia showing bone formation a week after a drill hole has been made. Restricted bone formation in cancellous bone may be due to differences in biology between the injured and the uninjured tissue. 


\section{Bone marrow cells respond - independently - to trauma}

With the intention to get a glimpse of what is happening during early cancellous bone healing, we conducted a pilot experiment to see what the healing of a drill hole in cancellous bone looked like during the first four days. Using a conventional light microscope, we could see how different types of inflammatory cells were changing their spatial localization, inside and around the healing drill hole, day by day.

While looking in the microscope, something else caught our attention: spindle-shaped cells appearing in the periphery of the healing drill hole, forming a circle around it, two days into healing (Figure 11). During the two following days of healing, we could see how these cells infiltrated further and further into the healing drill hole, until they occupied the whole region. Due to their morphology, we suspected that these spindle-shaped cells were of mesenchymal origin.

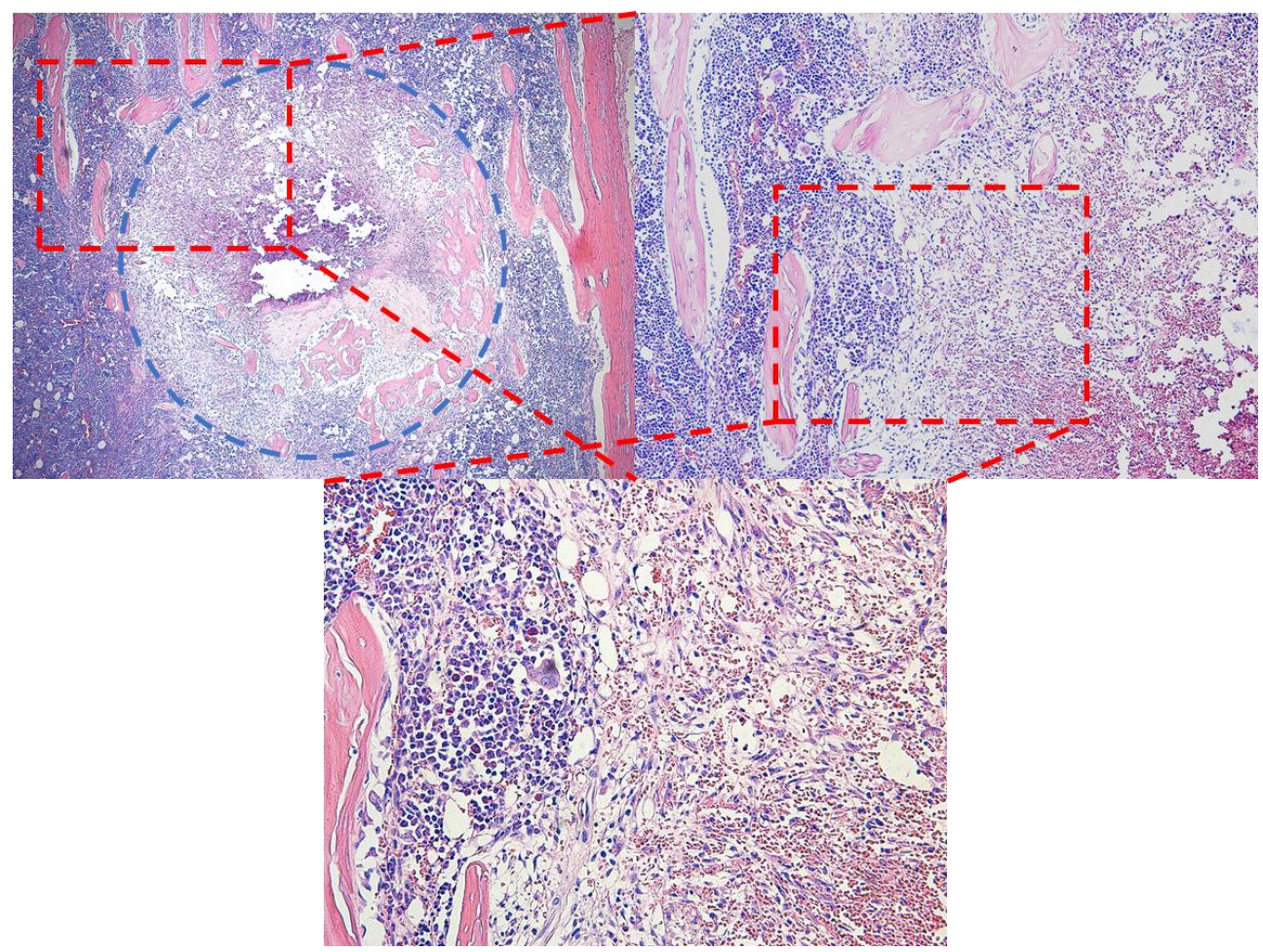

Figure 11. Drill hole (blue ring) in cancellous bone, two days after surgery. Spindle-shaped cells appeared in the periphery of the healing drill hole, encircling it.

To confirm our suspicion that these cells were mesenchymal, and osteogenic, we stained the cells for Runt-related transcription factor 2 (RUNX2): a marker expressed by preosteoblasts. With RUNX2, we could see that our spindle-shaped cells were early osteoblasts on their way to fill the drill hole with new bone tissue.

After this observation, we speculated that the mesenchymal cells, residing freely in the uninjured bone marrow, might be activated either by the mechanical stimuli of the trauma or by the initial inflammatory response to the trauma. Once activated, they migrate to the injured 
site and infiltrate it from the periphery, differentiating at the same time towards an osteogenic cell lineage - producing organic matrix which will develop into woven bone.

We think that the expansion of the bone formation can be used to estimate migration of osteogenic cells in vivo. In human biopsies of intersection from knee arthrodeses, the bone formation in the healing cancellous bone ranged from 0.6-1.2 millimeters and rarely exceeded 2 millimeters. ${ }^{29}$ We can see the same range of expansion in rat cancellous bone. Drill holes with a diameter of 1.2 millimeters have no problem to heal and new bone can be seen within them after a week. Drill holes with a diameter of 2 millimeters however, have difficulties to heal leaving the inner center of the drill hole with fibrous tissue (unpublished data). This suggests that osteogenic cells, in both humans and rats, all behave and respond the same, and that osteogenic cells have a limit on how far they can migrate and deposit bone - in cancellous bone at least.

With the encouraging results from the pilot experiment, seeing how inflammatory and osteogenic cells arrive and infiltrate the healing drill hole; we were now ready for a large-scale study: with more animals in each group and an additional time point (five days after trauma).

As in the pilot experiment, we could see how different types of inflammatory cells shifted in numbers over time in the healing drill hole, while osteogenic mesenchymal cells migrated into it and started to fill the hole with tissue that would become new woven bone eventually.

This observation, that inflammatory and mesenchymal cells appear simultaneously, differs from how shaft fracture healing is described in the literature; the common description is that accumulation of mesenchymal cells usually appears after the initial inflammation from inflammatory cells. ${ }^{6-12}$

\section{Inflammation and bone healing}

The time until bone formation starts in a shaft fracture can be as much as three times longer compared to cancellous bone. ${ }^{18}$ The poor availability of local mesenchymal cells in the shaft region, and the need for inflammatory signals to recruit mesenchymal cells from distant sources to the fracture, ${ }^{30-32}$ might contribute to this delay. Cancellous bone on the other hand is rich in mesenchymal cells, and responds to an injury with a local fracture healing response almost instantly. ${ }^{33,34}$

Moreover, it is not only the availability of mesenchymal cells that is important for bone healing, but also where in the bone the injury occurs. Depending on the location in the bone, multiple types of mesenchymal cells can be found; on the outer surface of the bone - the periosteal layer - mesenchymal cells will initiate a bone healing response based on the formation of cartilage (endochondral bone formation), while mesenchymal cells on the inner surface - the endosteal layer - are more prone to respond to trauma with direct bone formation. ${ }^{35,36}$

A previous study in mice showed that grafts of cortical bone with the periosteum and endosteum still attached, produced cartilage regardless of whether the periosteum faced outwards or inwards into a cortical defect. The endosteal side of the graft formed bone directly, irrespective of its orientation. ${ }^{36}$

Another characteristic of endosteal mesenchymal cells is that they show a greater cell proliferation, and ability to communicate and control inflammatory cells compared to those found in the central bone marrow. ${ }^{33,34}$ Endosteal mesenchymal cells are abundant in cancellous 
bone, since it mostly consists of trabeculae which are all lined with endosteum - giving cancellous bone its high regenerative potential.

The thought that shaft fractures rely on inflammation to heal is supported by the finding that anti-inflammatory drugs - which attenuate the inflammatory response to injury - impair shaft fracture healing, while cancellous bone healing is more or less unaffected: possibly enhanced..$^{20,21}$

\section{Inflammatory cells involvement in bone healing - Macrophages}

A growing number of studies demonstrate the immune systems involvement in fracture healing - including macrophages. ${ }^{37-41}$ Macrophages are a subtype of inflammatory cells responsible for removing debris and pathogens by engulfing them through phagocytosis and have also been shown to be important for fracture healing.

One way of studying the influence of cell types in vivo is to remove them from the system and monitor the consequences. Removal, also called depletion, of cells can be achieved by genetic manipulation or substance administration; one substance frequently used for macrophage depletion is clodronate liposomes. ${ }^{42-44}$ When injected in vivo, the liposomes are recognized as pathogens by the macrophages, that ingest them through phagocytosis. Once internalized, the clodronate induces cell inactivation or cell apoptosis.

To combine this depletion strategy with our drill hole model, rats received a single injection of clodronate liposomes intravenously either before or after drilling a hole in proximal tibia; the motivation of different injection time points was to monitor the importance of timing and arrival of macrophages to the injury.

One week later, we could see with microCT that the drill holes, which usually would be filled up with new bone, looked "empty" in the rats that had received clodronate prior to surgery (Figure 6A). Interestingly, the same effect was not seen in the rats that had received clodronate after surgery. Their bones appeared normal. Also, microscopic analysis of these "empty" drill holes showed a normal marrow stroma. It seemed as if the injured tissue in the drill hole had skipped the bone formation step and healed directly into normal marrow, without any scar tissue. However, earlier at day three, all samples - both treated and non-treated - looked the same. No cellular or morphological differences could be seen, and both macrophages and osteogenic cells were present.

This did not make any sense for us, we thought that the clodronate-treated rats would be depleted of macrophages or at least have less macrophages. Furthermore, how is it that we can see osteogenic cells within the drill holes at first, and no bone formation later?

We first speculated that circulating monocytes (macrophage precursor cells) had a significant role in the bone formation process. Our idea was that monocytes from peripheral blood would arrive in the injury from ruptured blood vessels upon trauma. The monocytes would then deposit molecules in the hematoma, like a "scent blueprint", which would attract osteogenic cells and initiate bone formation. By removing monocytes, using clodronate liposomes, this "scent blueprint" in the hematoma would be disturbed and impair the bone formation process.

However, after additional immunohistochemical studies (unpublished data), we could not see any reduction in neither the number of monocytes or macrophages in the initial hematoma nor in the adjacent marrow stroma. We now instead believe that the impaired effect on bone 
formation seen in our experiment is not due to monocyte/macrophage depletion, but of clodronate having a direct negative effect on osteoblasts and bone formation instead.

Bisphosphonates, including clodronate, have been shown to have an inhibitory effect on osteoblasts and bone mineral growth: ${ }^{45-51}$ mineral growth is affected by bisphosphonates high affinity to hydroxyapatite which can freeze mineral nucleation. ${ }^{49,50,52}$ Additionally, while clodronate may block mineral deposition, it does not affect the formation of extracellular matrix. ${ }^{48}$ Clodronate may accumulate in the bone marrow from either free clodronate, leaked from liposomes, or released from dying macrophages in the marrow. ${ }^{53}$

This may explain why we can see osteogenic cells in clodronate-treated drill holes and no bone formation later; the osteogenic cells may be in place, but their ability to deposit minerals has been suppressed by clodronate that is stuck in the extracellular matrix; or the clodronate binds to the minerals from the osteogenic cells and blocks further mineral nucleation. Furthermore, why we cannot see the same effect in the clodronate-treated drill holes after surgery might be that the clodronate cannot enter the hematoma due to disrupted blood flow.

In short, the impaired bone formation we could see from clodronate-liposome administration, is possibly due to inhibitory effects of clodronate itself on bone formation, and not macrophage depletion. For future macrophage-depletion studies in bone healing, an alternative depletion method might be considered instead of clodronate liposomes.

\section{Inflammatory cells involvement in bone healing - Cytotoxic T cells}

Another cell type that has received attention in fracture healing is the cytotoxic $\left(\mathrm{CD} 8^{+}\right) \mathrm{T}$ cell - lymphocytes involved in eliminating cancer-, or virus-infected cells. Our interest was triggered by a paper reporting that patients with elevated levels of a specific $\mathrm{CD}^{+}$ subpopulation showed delayed fracture healing. ${ }^{54}$ This paper included a supplementary study in mice with a femoral shaft fracture showing that removal of $\mathrm{CD}^{+}$cells enhanced bone formation, compared to mice that had elevated levels of $\mathrm{CD} 8^{+}$cells either naturally or by injection of extra cells.

We could not find any previous studies considering $\mathrm{CD} 8^{+}$cells and cancellous bone healing. Without further ado, we planned an experiment to prove the hypothesis that depletion of CD8 ${ }^{+}$ cells would have a positive effect on cancellous bone healing. For the experiment we used an antibody which recognizes and depletes $\mathrm{CD} 8^{+}$cells in the blood circulation when administered. We injected the antibody in rats 24 hours before bilateral drill holes where made in proximal tibiae, in which one of the holes received a steel screw.

After a week, the screws were pulled out while measuring the pull-out force. Contrary to our hypothesis, we saw a negative effect in animals with depleted $\mathrm{CD} 8^{+}$cells: the force used to pull-out of the screws was lower compared to controls. Although depletion of $\mathrm{CD} 8^{+}$cells did not seem to affect bone formation in the drill holes without screws.

We had difficulties to interpret these results, but a previous study about shaft fractures showed that transgenic mice without any $\mathrm{T}$ cells (and B cells) showed a soft callus with disorganized collagen matrix and stiffer, more brittle bones. ${ }^{55}$ In contrast, we saw a lower stiffness in our study. This difference can be explained by differences in the animal models used. While the other study was in mice with shaft fractures (cortical bone), with no T cells at all; our study was in rats and cancellous bone, where we depleted just $\mathrm{CD}^{+}$cells. Even though the study was 
different from ours, the observed initial disorganized collagen matrix helped us speculate about our results.

We were not able to see any disorganized collagen in our samples, but that could be that we looked at a later time point where the collagen structure cannot be distinguished. If we looked at an earlier time point, we have might been able to see this disorganization as well. Nonetheless, this disorganization might be the cause for the lower pull-out force of the screws we saw in our study.

In brief, we speculate that $\mathrm{CD} 8^{+}$cells are involved in the organization of the initial collagen formation. If the $\mathrm{CD} 8^{+}$cells are gone, the collagen matrix becomes less organized, which leads to bone with a lower structural strength.

\section{The fracture hematoma}

How come inflammatory cells are important for bone formation when they are not directly involved in the process? Fractures cause blood vessels in the bone to rupture, leaking blood into the tissue and forming a hematoma - blood clot. ${ }^{4,6,56}$ The hematoma is a hostile world for cells, with low oxygen levels and low $\mathrm{pH}$, and not many cells can endure in such surroundings. ${ }^{6,9,57-}$ 59

Inflammatory cells however are more resilient to such conditions and can infiltrate the hematoma. ${ }^{60-62}$ Once inside the hematoma, inflammatory cells send signals to attract other cell types (e.g. mesenchymal cells) to migrate to the zone of injury. ${ }^{4,56,63}$ This makes the hematoma an important supply of cells and factors which are necessary for inducing a healing response. . $^{1,58,59}$

Without inflammatory cells to show the way, other cells cannot enter the hematoma/injury and start the healing process, ${ }^{64}$ and removal of the hematoma leads to impaired fracture healing. $6,65,66$

A previous study showed the hematomas healing potential by taking hematomas from fractures in rats and transplant them in other tissues; ${ }^{67}$ when placed in muscle tissue, the hematoma would still form bone tissue. One could think of fracture hematomas as preprogrammed bone-forming packages.

\section{Cortical bone cannot heal without the influence from bone marrow}

For a study in mice, ${ }^{68}$ we had developed a model to study the influx of inflammatory cells in a cortical bone defect. In the model, we removed a portion of the cortical bone in the femur midshaft to get into the marrow compartment before the marrow was scooped out (Figure 12A).

The study included complementary histology of the healing defects just out of curiosity. Looking in the microscope, we could see in the marrow ablated bones a fast regeneration of new marrow-like tissue, not bone. This new marrow filled the former emptied marrow compartment, with mesenchymal cells residing just where the cortical bone was removed producing new bone (Figure 12B). Once again, we witnessed this delineation between bone marrow and bone formation. 

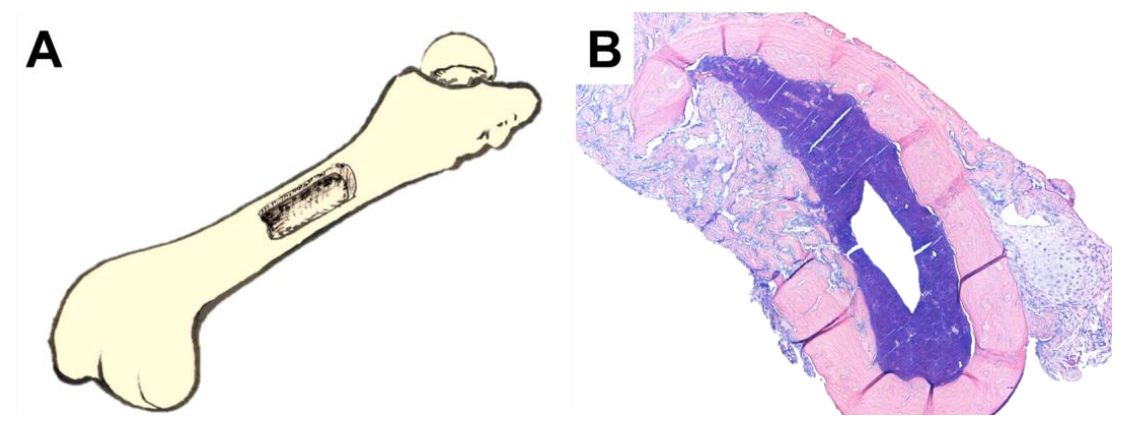

Figure 12. A) Cortical bone defect model - midportion of the femur cortical bone is milled away before the marrow is scooped out. B) Cortical bone defect, five-days-old; the former emptied marrow compartment regenerated, and bone formation could be seen in the cortical gap. Note the strict border between new bone and marrow (purple).

It is thought that the healing of cortical bone is derived from cells from external sources such as the periosteum, surrounding soft tissue (muscles), and blood circulation..$^{30-32,69,70}$ Whereas from the looks of our cortical defects, we speculated if the healing might be derived from the newly regenerated marrow.

These thoughts evolved to the hypothesis that osteogenic cells from the marrow compartment are important for cortical bone healing. We hypothesized that if we could obstruct the cell migration from the uninjured marrow adjacent to the cortical defect, the healing would be impaired.

For this experiment, we now also included a group of mice that got silicone plugs inserted into the marrow compartment after removing the cortical bone and marrow. The silicone plugs were placed proximally and distally of the cortical defect and would act as barriers, preventing cells from the uninjured marrow to enter the defect (Figure 13A). Interestingly, when the marrow was blocked with a silicone plug on both sides of the defect, it would not heal at all: the emptied marrow compartment did not regenerate new marrow-like tissue, as in the controls, and no cells or bone formation could be seen in the cortical gap (Figure 13B).
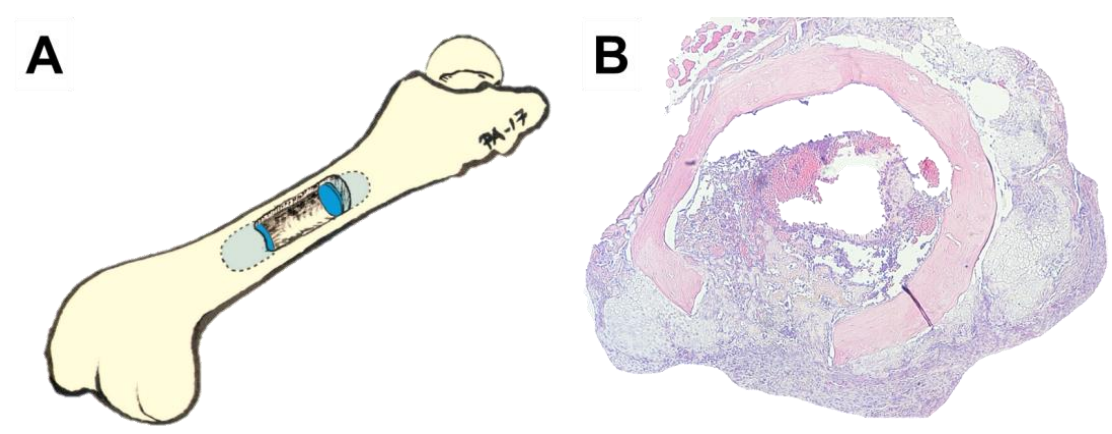

Figure 13. (A) Cortical defect model with two silicone plugs inserted proximal and distal to the defect blocking uninjured marrow in the ends of the bone from entering the defect. (B) Cortical defect with silicone plugs, ten-days-old; when the marrow was blocked, no regeneration of the marrow compartment or bone formation in the cortical gap could be seen. 
This suggests that external sources such as the periosteum, adjacent muscle tissue, and blood circulation are not enough to induce a proper healing process in cortical bone, but internal signals from an intact or regenerated bone marrow are necessary as well. This is might be of importance when treating for example pseudarthroses and skeletal defects in the clinic. For a successful pseudarthrosis treatment, where the defect is filled with cement followed by bone transplantation, it is thought that the defect needs to have contact with adjacent intact marrow, ${ }^{71,72}$ this thought is supported by our findings.

However, it is important to note that that our results may not be transferable to humans because the murine diaphyseal bone marrow is haematopoietically more active compared to humans, which is more adipose. ${ }^{73}$

\section{Animal models vs. human patients}

Even though humans and murines (rats and mice) share rather comparable physiological features (e.g. immune system, cell types, response to injuries), there are several differences that need to be considered.

For example, murines are quadrupeds and load their bones differently from how humans do who are bipeds. These biomechanical differences might influence the healing pattern in fractures. Moreover, while humans would not dream of putting load on a newly fractured leg due to the pain, evolution has pushed murines to not show any weaknesses. A rat or mouse will walk on a newly fractured leg, while trying to hide their limp in order to avoid being targeted by potential predators. A fracture in a mouse or rat will therefore be exposed to mechanical forces during the initial healing phase, which would not be the same in a human.

Another, and probably the most crucial difference, is that murines are considerably smaller than humans, while the cell size is still the same. This means that a wound that is proportionally the same size between a human and murine will be perceived very differently by a cell. For a cell, a fractured femur in a human is a significantly larger injury compared to a fractured femur in a rat or mouse. Because of this, a fracture in a murine will heal in less time and with less potential consequences compared to a human, since the overall spaces will be smaller for the cells to cover and regenerate.

With all the differences between humans and murines, the use and relevance of using murines as animal models in studying fracture healing can be questioned. Can the results acquired from animal studies really be applied to human patients? Animal models are not used to attain results than can be translated directly into a patient's situation; animal models are used to study concepts in a controlled setting in order to generate reproducible data in a standardized way.

The benefits with murine models on the other hand, are that you can obtain results in a relatively short time, they are cheap, and comes with less ethical requirements compared to larger animals.

Hopefully, our results from using animal models will lead to new insights and a better understanding of the processes involved in fracture healing - helping doctors and patients in the future. 


\section{SUMMARY AND REMARKS FOR FUTURE RESEARCH}

Compared to shaft-fracture healing, concerning cortical bone mostly, cancellous bone heals more rapidly with minor soft callus formation. Cancellous bone is rich in mesenchymal and inflammatory cells that upon trauma can dispatch an almost immediate healing response. Together, mesenchymal and inflammatory cells organize bone formation that is very restricted to the confinements of the injury. We believe that the initial hematoma after trauma is the reason for this restricted bone formation.

Upon trauma, blood vessels rupture and blood fill out the injured tissue, forming a hematoma. The hematoma houses inflammatory cells which recruits mesenchymal cells from the uninjured adjacent marrow. Once inside the hematoma, the mesenchymal cells start to proliferate and fill it out while they differentiate into osteogenic lineage. The hematoma functions similarly to a scaffold and is eventually replaced with woven bone. However, this rapid bone formation seems to come with a price.

Others have made observations in humans, and we in rat, that the bone formation in cancellous bone will not expand further than a couple of millimeters. We speculate that osteogenic mesenchymal cells are only able to migrate a certain distance before they settle and deposit bone. This observation may be of clinical importance when working with injuries and treatments in cancellous bone, especially arthrodeses and larger skeletal defects. If the gaps between healing surfaces exceed more than a couple of millimeters, the greater the risk for a compromised healing. For future and further investigating of this localized bone formation in cancellous bone, we think focus should lie on the function and influence of the initial hematoma on healing.

We also found that adjacent, uninjured marrow is important for the healing of cortical bone defects in mice. The marrow seems to supply with crucial factors for a functional healing response, and if the marrow is blocked from reaching the defect the healing is greatly impaired. In clinical practice, allowing adjacent marrow to have access to skeletal defects as much as possible is something to take into consideration. In this study we only focused on blocking the interior influx of factors from the marrow compartment to the injury, in the future it would be interesting to develop a model which instead blocks factors from the exterior (e.g. the periosteum). Would the marrow be able to heal the cortical defect on itself, or is the healing dependent on contribution from external sources as well?

Even if it seems that inflammatory suppression (using anti-inflammatory drugs) does not affect cancellous bone healing, depletion of inflammatory subpopulations can have a detrimental effect on the healing process. Inflammation is, among other things, responsible for recruiting inflammatory and mesenchymal cells to the injured site. If the inflammation is suppressed, so is the recruitment of cells; this will have dramatic effects in tissues which have rather few resident cells (e.g. cortical bone) and rely on the recruiting function of the inflammation. For tissues that are already rich in resident cells (e.g. cancellous bone), this is not a problem since 
the cells can respond and initiate healing locally. However, with systemic cell depletion you eliminate a great portion of a subpopulation that might have an important part in the healing process.

We could see that depletion of $\mathrm{CD}^{+}$cells impaired implant fixation in cancellous bone, suggesting that $\mathrm{CD}^{+}$cells might be involved in the healing response in cancellous bone. Although we were not able to present a possible mechanism of how $\mathrm{CD}^{+}$cells influence healing, we believe that analyzing the early gene expression in the healing tissue would be a good start.

In this thesis we have addressed a few mechanisms that we have observed in cancellous bone healing. Nonetheless, fractures are of a complex nature and most often concerns both cortical and cancellous bone. Fracture healing is a rather vague term actually, and one of the greatest challenges in orthopaedic research is to find variables that represent fracture healing. Because when is a fracture healed really? Is it when its radiological appearance looks healed; the patient can put weight on the fractured bone; the patient does not feel any pain anymore; or is it when the fractured bone is totally remodeled? 


\section{REFERENCES}

1. Schmidt-Bleek, K. et al. Cellular composition of the initial fracture hematoma compared to a muscle hematoma: a study in sheep. J. Orthop. Res. 27, 1147-1151 (2009).

2. Kolar, P. et al. The early fracture hematoma and its potential role in fracture healing. Tissue Eng. Part B. Rev. 16, 427-434 (2010).

3. Konnecke, I. et al. T and B cells participate in bone repair by infiltrating the fracture callus in a two-wave fashion. Bone 64, 155-165 (2014).

4. Hankenson, K. D., Gagne, K. \& Shaughnessy, M. Extracellular signaling molecules to promote fracture healing and bone regeneration. Adv. Drug Deliv. Rev. 94, 3-12 (2015).

5. Loi, F. et al. Inflammation, fracture and bone repair. Bone 86, 119-130 (2016).

6. Shiu, H. T., Leung, P. C. \& Ko, C. H. The roles of cellular and molecular components of a hematoma at early stage of bone healing. J. Tissue Eng. Regen. Med. 12, e1911e1925 (2018).

7. Schindeler, A., McDonald, M. M., Bokko, P. \& Little, D. G. Bone remodeling during fracture repair: The cellular picture. Semin. Cell Dev. Biol. 19, 459-466 (2008).

8. Marsell, R. \& Einhorn, T. A. The biology of fracture healing. Injury 42, 551-555 (2011).

9. Claes, L., Recknagel, S. \& Ignatius, A. Fracture healing under healthy and inflammatory conditions. Nat. Rev. Rheumatol. 8, 133-143 (2012).

10. Einhorn, T. A. \& Gerstenfeld, L. C. Fracture healing: mechanisms and interventions. Nat. Rev. Rheumatol. 11, 45-54 (2015).

11. El-Jawhari, J. J., Jones, E. \& Giannoudis, P. V. The roles of immune cells in bone healing; what we know, do not know and future perspectives. Injury 47, 2399-2406 (2016).

12. Ono, T. \& Takayanagi, H. Osteoimmunology in Bone Fracture Healing. Curr. Osteoporos. Rep. 15, 367-375 (2017).

13. Baht, G. S., Vi, L. \& Alman, B. A. The Role of the Immune Cells in Fracture Healing. Curr. Osteoporos. Rep. 16, 138-145 (2018).

14. Hedstrom, E. M., Svensson, O., Bergstrom, U. \& Michno, P. Epidemiology of fractures in children and adolescents. Acta Orthop. 81, 148-153 (2010).

15. Driessen, J. H. M. et al. The epidemiology of fractures in Denmark in 2011. Osteoporos. Int. 27, 2017-2025 (2016).

16. Han, D., Han, N., Xue, F. \& Zhang, P. A novel specialized staging system for cancellous fracture healing, distinct from traditional healing pattern of diaphysis corticalfracture? Int. J. Clin. Exp. Med. 8, 1301-1304 (2015).

17. Chen, W. T. et al. A special healing pattern in stable metaphyseal fractures. Acta Orthop. 86, 238-242 (2015).

18. Sandberg, O. H. \& Aspenberg, P. Inter-trabecular bone formation: a specific mechanism for healing of cancellous bone. Acta Orthop. 87, 459-465 (2016).

19. Inoue, S., Otsuka, H., Takito, J. \& Nakamura, M. Decisive differences in the bone repair processes of the metaphysis and diaphysis in young mice. Bone Reports 8, 1-8 (2018).

20. Sandberg, O. \& Aspenberg, P. Different effects of indomethacin on healing of shaft and metaphyseal fractures. Acta Orthop. 86, 243-247 (2015).

21. Sandberg, O. H. \& Aspenberg, P. Glucocorticoids inhibit shaft fracture healing but not metaphyseal bone regeneration under stable mechanical conditions. Bone Joint Res. 4, 170-175 (2015).

22. Sandberg, O., Bernhardsson, M. \& Aspenberg, P. Earlier effect of alendronate in mouse metaphyseal versus diaphyseal bone healing. J. Orthop. Res. 35, (2017).

23. Aspenberg, P. \& Sandberg, O. Distal radial fractures heal by direct woven bone 
formation. Acta Orthop. 84, 297-300 (2013).

24. Ghayor, C. \& Weber, F. E. Osteoconductive Microarchitecture of Bone Substitutes for Bone Regeneration Revisited. Front. Physiol. 9, 960 (2018).

25. Jarvinen, T. L., Sievanen, H., Jokihaara, J. \& Einhorn, T. A. Revival of bone strength: the bottom line. Journal of bone and mineral research: the official journal of the American Society for Bone and Mineral Research 20, 717-720 (2005).

26. Leppanen, O., Sievanen, H., Jokihaara, J., Pajamaki, I. \& Jarvinen, T. L. N. Three-point bending of rat femur in the mediolateral direction: introduction and validation of a novel biomechanical testing protocol. J. Bone Miner. Res. 21, 1231-1237 (2006).

27. Sandberg, O., Macias, B. R. \& Aspenberg, P. Low dose PTH improves metaphyseal bone healing more when muscles are paralyzed. Bone 63, 15-19 (2014).

28. Bernhardsson, M., Sandberg, O. \& Aspenberg, P. Anti-RANKL treatment improves screw fixation in cancellous bone in rats. Injury 46, (2015).

29. CHARNLEY, J. \& BAKER, S. L. Compression arthrodesis of the knee; a clinical and histological study. J. Bone Joint Surg. Br. 34-B, 187-199 (1952).

30. Kumagai, K., Vasanji, A., Drazba, J. A., Butler, R. S. \& Muschler, G. F. Circulating cells with osteogenic potential are physiologically mobilized into the fracture healing site in the parabiotic mice model. J. Orthop. Res. (2008). doi:10.1002/jor.20477

31. Liu, R. et al. Myogenic progenitors contribute to open but not closed fracture repair. BMC Musculoskelet. Disord. 12, 288 (2011).

32. Neagu, T. P., Tiglis, M., Cocolos, I. \& Jecan, C. R. The relationship between periosteum and fracture healing. Rom. J. Morphol. Embryol. = Rev. Roum. Morphol. Embryol. 57, 1215-1220 (2016).

33. Suh, K. T. et al. MRI of the proximal femur predicts marrow cellularity and the number of mesenchymal stem cells. J. Magn. Reson. Imaging 35, 218-222 (2012).

34. Siclari, V. A. et al. Mesenchymal progenitors residing close to the bone surface are functionally distinct from those in the central bone marrow. Bone 53, 575-586 (2013).

35. Rabie, A. B., Dan, Z. \& Samman, N. Ultrastructural identification of cells involved in the healing of intramembranous and endochondral bones. Int. J. Oral Maxillofac. Surg. 25, 383-388 (1996).

36. Colnot, C. Skeletal cell fate decisions within periosteum and bone marrow during bone regeneration. J. Bone Miner. Res. 24, 274-282 (2009).

37. Chang, M. K. et al. Osteal Tissue Macrophages Are Intercalated throughout Human and Mouse Bone Lining Tissues and Regulate Osteoblast Function In Vitro and In Vivo. J. Immunol. 181, 1232-1244 (2008).

38. Sandberg, O. H., Tätting, L., Bernhardsson, M. E. \& Aspenberg, P. Temporal role of macrophages in cancellous bone healing. Bone 101, 129-133 (2017).

39. Vi, L. et al. Macrophages promote osteoblastic differentiation in-vivo: implications in fracture repair and bone homeostasis. J. Bone Miner. Res. 30, 1090-1102 (2015).

40. Raggatt, L. J. et al. Fracture healing via periosteal callus formation requires macrophages for both initiation and progression of early endochondral ossification. J. Bone Miner. Res. 30, 3192-3204 (2011).

41. Schlundt, C. et al. Macrophages in bone fracture healing: Their essential role in endochondral ossification. Bone 106, 78-89 (2018).

42. Moreno, S. G. Depleting Macrophages In Vivo with Clodronate-Liposomes. Methods Mol. Biol. 1784, 259-262 (2018).

43. Van Rooijen, N. \& Sanders, A. Liposome mediated depletion of macrophages: mechanism of action, preparation of liposomes and applications. J. Immunol. Methods 174, 83-93 (1994).

44. Chow, A. et al. Bone marrow CD169+ macrophages promote the retention of 
hematopoietic stem and progenitor cells in the mesenchymal stem cell niche. J. Exp. Med. 208, 261-271 (2011).

45. Idris, A. I., Rojas, J., Greig, I. R., Van't Hof, R. J. \& Ralston, S. H. Aminobisphosphonates cause osteoblast apoptosis and inhibit bone nodule formation in vitro. Calcif. Tissue Int. 82, 191-201 (2008).

46. Manzano-Moreno, F. J., Ramos-Torrecillas, J., De Luna-Bertos, E., Ruiz, C. \& GarciaMartinez, O. High doses of bisphosphonates reduce osteoblast-like cell proliferation by arresting the cell cycle and inducing apoptosis. J. Craniomaxillofac. Surg. 43, 396-401 (2015).

47. Kellinsalmi, M. et al. In vitro comparison of clodronate, pamidronate and zoledronic acid effects on rat osteoclasts and human stem cell-derived osteoblasts. Basic Clin. Pharmacol. Toxicol. 97, 382-391 (2005).

48. Orriss, I. R., Key, M. L., Colston, K. W. \& Arnett, T. R. Inhibition of osteoblast function in vitro by aminobisphosphonates. J. Cell. Biochem. 106, 109-118 (2009).

49. Fleisch, H. A., Russell, R. G., Bisaz, S., Muhlbauer, R. C. \& Williams, D. A. The inhibitory effect of phosphonates on the formation of calcium phosphate crystals in vitro and on aortic and kidney calcification in vivo. Eur. J. Clin. Invest. 1, 12-18 (1970).

50. Nancollas, G. H. et al. Novel insights into actions of bisphosphonates on bone: differences in interactions with hydroxyapatite. Bone 38, 617-627 (2006).

51. Nyman, M. T., Gao, T., Lindholm, T. C. \& Lindholm, T. S. Healing of a tibial double osteotomy is modified by clodronate administration. Arch. Orthop. Trauma Surg. 115, 111-114 (1996).

52. Ruiz, J. L., Hutchesson, J. D. \& Aikawa, E. Unraveling the Controversy of Bisphosphonates as Vascular Calcification Therapy Using a Nanoanalytical Approach [abstract from the American Heart Association's Arteriosclerosis, Thrombosis and Vascular Biology/Peripheral Vascular Disease 2016 Scientific Sessions]. Arterioscler. Thromb. Vasc. Biol. 36, A658 (2017).

53. Clodrosone. Systemic Administration of Clodronate Liposomes via Intravenous Injection. Available at: https://www.clodrosome.com/routes-ofadministration/intravenous/. (Accessed: 11th October 2018).

54. Reinke, S. et al. Terminally differentiated $\mathrm{CD}^{+} \mathrm{T}$ cells negatively affect bone regeneration in humans. Sci. Transl. Med. 5, 177 ra36 (2013).

55. El Khassawna, T. et al. T Lymphocytes Influence the Mineralization Process of Bone. Front. Immunol. 8, 562 (2017).

56. Echeverri, L. F., Herrero, M. A., Lopez, J. M. \& Oleaga, G. Early stages of bone fracture healing: formation of a fibrin-collagen scaffold in the fracture hematoma. Bull. Math. Biol. 77, 156-183 (2015).

57. Kolar, P., Gaber, T., Perka, C., Duda, G. N. \& Buttgereit, F. Human early fracture hematoma is characterized by inflammation and hypoxia. Clin. Orthop. Relat. Res. 469, 3118-3126 (2011).

58. Wang, X., Friis, T., Glatt, V., Crawford, R. \& Xiao, Y. Structural properties of fracture haematoma: current status and future clinical implications. J. Tissue Eng. Regen. Med. 11, 2864-2875 (2017).

59. Wang, X., Zhang, Y., Ji, W. \& Ao, J. Categorising bone defect hematomas - Enhance early bone healing. Med. Hypotheses 113, 77-80 (2018).

60. Roiniotis, J. et al. Hypoxia prolongs monocyte/macrophage survival and enhanced glycolysis is associated with their maturation under aerobic conditions. J. Immunol. 182, 7974-7981 (2009).

61. Nakagawa, Y. et al. Effects of extracellular $\mathrm{pH}$ and hypoxia on the function and development of antigen-specific cytotoxic T lymphocytes. Immunol. Lett. 167, 72-86 
(2015).

62. Riemann, A. et al. Acidosis differently modulates the inflammatory program in monocytes and macrophages. Biochim. Biophys. Acta 1862, 72-81 (2016).

63. Yellowley, C. CXCL12/CXCR4 signaling and other recruitment and homing pathways in fracture repair. Bonekey Rep. 2, 300 (2013).

64. Schmidt-Bleek, K. et al. Inflammatory phase of bone healing initiates the regenerative healing cascade. Cell Tissue Res. 347, 567-573 (2012).

65. Grundnes, O. \& Reikeras, O. The importance of the hematoma for fracture healing in rats. Acta Orthop. Scand. 64, 340-342 (1993).

66. Park, S.-H., Silva, M., Bahk, W.-J., McKellop, H. \& Lieberman, J. R. Effect of repeated irrigation and debridement on fracture healing in an animal model. J. Orthop. Res. 20, 1197-1204 (2002).

67. Mizuno, K. et al. The osteogenetic potential of fracture haematoma. Subperiosteal and intramuscular transplantation of the haematoma. J. Bone Joint Surg. Br. 72, 822-829 (1990).

68. Tätting, L., Sandberg, O., Bernhardsson, M., Ernerudh, J. \& Aspenberg, P. Different leukocyte composition in cortical and cancellous bone healing: A comparison in mice. Bone Jt. Res. (In-press).

69. Shirley, D., Marsh, D., Jordan, G., McQuaid, S. \& Li, G. Systemic recruitment of osteoblastic cells in fracture healing. J. Orthop. Res. 23, 1013-1021 (2005).

70. Murao, H., Yamamoto, K., Matsuda, S. \& Akiyama, H. Periosteal cells are a major source of soft callus in bone fracture. J. Bone Miner. Metab. 31, 390-398 (2013).

71. Giannoudis, P. V, Faour, O., Goff, T., Kanakaris, N. \& Dimitriou, R. Masquelet technique for the treatment of bone defects: tips-tricks and future directions. Injury $\mathbf{4 2 ,}$ 591-598 (2011).

72. Auregan, J.-C. \& Begue, T. Induced membrane for treatment of critical sized bone defect: a review of experimental and clinical experiences. Int. Orthop. 38, 1971-1978 (2014).

73. Hardouin, P., Rharass, T. \& Lucas, S. Bone Marrow Adipose Tissue: To Be or Not To Be a Typical Adipose Tissue? Front. Endocrinol. (Lausanne). 7, 85 (2016). 